\title{
THE REACTION OF OLEIC ACID WITH A MIXTURE OF ETHAN OLAMINES
}

\author{
Stepan M elnyk ${ }^{1, *}$, Roman Danyliuk ${ }^{1}$, Yuriy M elnyk $^{1}$, Victor Reutskyy $^{1}$
}

https://doi.org/10.23939/chcht12.01.013

\begin{abstract}
Regularities of the reaction of oleic acid with a mixture of ethanolamines have been investigated under non-stationary conditions in the presence of $\mathrm{H}$-form of cation-exchange resin KU-2-8 as a catalyst. The effect of a ratio between reagents and the catalyst on the acid conversion, selectivity and products yield has been determined. $\mathrm{N}$-acylation of mono- and diethanolamines by an oleic acid was found to be more intensive compared with esterification of hydroxy groups of ethanolamine.
\end{abstract}

Keywords: oleic acid, ethanolamines, catalyst, cation exchange resin, selectivity.

\section{Introduction}

The products of the reaction of amino alcohols with higher fatty acids are used for the production of surfaceactive substances, corrosion inhibitors, antistatic substances for textile industry and household chemical goods, etc. [1, 2]. They are produced under various temperatures using different catalysts or without them.

In particular, diesters of free fatty acids separated from beef fat and triethanolamines are synthesized in the presence of sodium methylate and phosphoric acid at $408 \mathrm{~K}$ with the yields of 72.54 and $81.55 \%$, respectively [3]. In the same way monoethanolamine esteramides or diesters of triethanolamine and tall oil fatty acid are obtained at $443 \mathrm{~K}$ in the presence of phosphoric acid. The treatment of reaction products by dimethylsulfate and benzylchloride allows to produce quaternary salts which provide good wetting of a tissue [4].

Oil-soluble corrosion inhibitors of ferrous metals which are based on esters and amides of oleic acid are obtained by sequential esterification at $408-413 \mathrm{~K}$ and amidation at $453-463 \mathrm{~K}$. Triethanolamine is used as an esterification reagent, and monoethanolamine, diethanolamine, polyamines, etc. are used for acid amidation. The process proceeds without a catalyst [5].

\footnotetext{
${ }^{1}$ Lviv Polytechnic National Univeristy

12, S.Bandera St., 70013 Lviv, Ukraine;

stepan.r.melnyk@lpnu.ua

(c) Melnyk S., Danyliyuk R., Melnyk Yu., Reutskyy V., 2018
}

To obtain nonionic emulsifiers - diethanolamides of fatty acids - the catalysis is applied using enzyme Candida antarctica lipase (Novozym 435). The reaction occurs at low temperature ( $323 \mathrm{~K}$ ) for $24 \mathrm{~h}$ and is characterized by the decrease in diethanolamides yield with the increase in length of the carboxylic acids C-chain. The yields of hexanoyl diethanolamide, lauroyl diethanolamide, and oleoyl diethanolamide are $76.5,49.5$ and $12.1 \%$, respectively. Enzymatic catalysis is sensitive to the presence of metal and water ions in the reaction medium [6].

As a catalyst for fatty acids esterification by triethanolamine or methyldiethanolamine the complex compound of platinum(II) $\mathrm{H}_{2}\left[\mathrm{Pt}(\mathrm{CN})_{4}\right] \cdot 3 \mathrm{H}_{2} \mathrm{O}$ is applied in an amount of $0.05-0.1 \mathrm{wt} \%$. The reaction proceeds at $453 \mathrm{~K}$ for $1 \mathrm{~h}$ with $99 \%$ yield of amino alcohol diesters [7].

Aprotic catalysts, metal salts in particular, are very active in esterification processes [8]. However, their application for catalysis is complicated by possible complexation of metal ions with nitrogen-containing compounds, solubility in the reaction mixture and complicity of products purification from the catalyst.

When using technical mixtures of ethanolamines it is possible to reduce the price of raw material and diversify the composition of resulting products. The combination of esteric and amide functional groups in the resulting products provides the variety of their operational characteristics and extend the area of application. The development of methods for determination of products composition, products ratio and effect of catalyst nature on the simultaneous proceeding of esterification and $\mathrm{N}$ acylation reactions is an important task.

The aims of the present work are to investigate the regularities of the reaction of oleic acid with the mixture of ethanolamines under non-stationary conditions in the presence of the catalyst - KU-2-8 cationite fnd to determine the effect of process parameters on the operational characteristics.

\section{Experimental}

The reagents were oleic acid (acid value $194 \mathrm{mgKOH} / \mathrm{g}$; purity $97.8 \%$ ) and technical mixture of 
ethanolamines (di- and triethanolamine, mainly). KU-2-8 cationite was used as a catalyst, its static exchange capacity is $1.8 \mathrm{mmol}-\mathrm{eq} / \mathrm{g} \mathrm{H}^{+}$ions. The catalyst $p$-toluenesulfonic acid ( $p$ TSA) was used for comparison. Benzene was added to the reagents for easier removal of water from the reaction mixture.

The reaction of oleic acid with a mixture of ethanolamines was studied under non-stationary conditions, in a round-bottom flask under mechanical stirring and temperature control and in a flask equipped with Dean-Stark trap, back condenser and magnetic stirrer. In the first case the reaction temperature was $403 \mathrm{~K}$, in the second - the temperature corresponded to the boiling point of the reaction mixture $(379 \mathrm{~K})$.

The content of monoethanolamine in the mixture of ethanolamines was determined using a gas-liquid chromatograph "Tsvet-100" with a thermal conductivity detector and column ( $1 \mathrm{~m}$ length and $3 \mathrm{~mm}$ diameter) filled by 5\% Silicone SE30 over Chromaton N-AW. Helium was a carrier gas (flow rate of $3 \mathrm{dm}^{3} / \mathrm{h}$ ); current strength of the detector $140 \mathrm{~mA}$; sample volume $2 \mu \mathrm{l}$. The temperature of an evaporator was $523 \mathrm{~K}$, detector $493 \mathrm{~K}$; column - $423 \mathrm{~K}$. Mass part of monoethanolamine in the mixture was calculated using an absolute calibration method. Isopropyl alcohol was a solvent. Chromatographic analysis showed the presence of non-identified impurity in the amount of $2.6 \mathrm{wt} \%$ (according to the peak of monoethanolamine).

Water content in the mixture of ethanolamines was determined using distillation with $n$-xylene by measuring volume [9]. This method is correct because ethanolamines do not form azeotropic mixtures with water [10]. Water content was $1.7 \mathrm{wt} \%$.

The amount of di- and triethanolamines was calculated using a determined content of monoethanolamine, impurity, water and total amine value of ethanolamines mixture (average molecular weight $\sim 124$ ). The mixture consists of (wt \%): monoethanolamine (MEA) - 1.5; diethanolamine (DEA) - 40.2 and triethanolamine (TEA) - 54.0.

To calculate the amine value $(\mathrm{AmV})$ of the reaction mixture and mixture of ethanolamines, as well as acid value $(A V)$ of the products we used a conductometric titration of the mentioned compounds by $0.1 \mathrm{M}$ solutions of $\mathrm{HCl}$ and $\mathrm{NaOH}$, respectively. Typical titration curves given in Fig. 1 show this method is suitable to determine the carboxy and amine groups in the mixture. The measurement error did not exceed $2.8 \%$.

According to the acid values of reagents mixture and reaction products and taking into account the material balance, we calculated the conversion of oleic acid:

$$
K_{O A}=\frac{A V_{0} \cdot m_{0}-A V \cdot m}{A V_{0} \cdot m} \cdot 100 \%
$$

where $A V_{0}$ and $A V$ - initial and current acid value of the reaction mixture, $\mathrm{mgKOH} / \mathrm{g} ; m_{0}$ and $m-$ initial and current weight of the reaction mixture, $g$.

The amine value was used to control the amount of reacted aminogroups.

Since ethanolamines in the mixture contain at least two reaction groups, then there was a lack of oleic acid (OA) in all experiments. So, the selectivity of the reaction products and their yield were calculated according to OA.

Selectivity of the amides formation was calculated according to the formula (2):

$$
S_{A m d}^{O A}=\frac{n_{A m, 0}-n_{A m, f i n}}{n_{O A, 0}-n_{O A, f i n}}
$$

where $n_{A m, 0}$ and $n_{A m, f i n}$ - initial and final amount of moles of aminogroups in the reaction mixture; $n_{O A, 0}$ and $n_{O A, f i n}-$ initial and final amount of moles of carboxy groups in the reaction mixture.

The amount of unreacted amines in the reaction products is:

$$
n_{A m, f i n}=\frac{A m V_{f i n} \cdot m}{36500}
$$

where $A_{m} V_{f i n}$ - amine value of the reaction products, $\mathrm{mgHCl} / \mathrm{g} ; m$ - weight of the reaction products, $\mathrm{g}$.

The selectivity of the esters formation was calculated according to the formula (4):

$$
S_{E}^{O A}=\frac{\left(n_{O A, 0}-n_{O A, f i n}\right)-\left(n_{A m, 0}-n_{A m, f i n}\right)}{n_{O A, 0}-n_{O A, f i n}}
$$

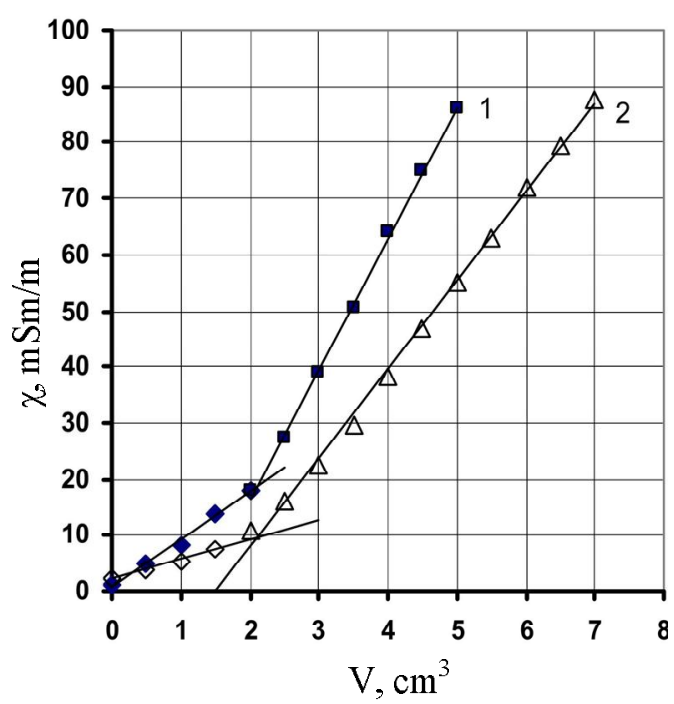

Fig. 1. Electroconductivity $v s$. volume of added titrant at the determination of amine value (1) and acid value (2)

The yield of the reaction products was calculated as a product of OA conversion and selectivity of formation of the products with amide and esteric bonds. 


\section{Results and Discussion}

The reaction of $\mathrm{OA}$ with the ethamolamines mixture involves consecutive reactions of $N$-acylation products formation - hydroxyethyloctadec-9-enamides (HEODA) and $O$-acylation (esterification) - imino- or aminoethyloctadec-9-enoates (AEODA), Figs. 2-4.

Obviously, the composition of the products is provided by the reactivity of reagents and semiproducts, reagents ratio and reaction time. The final products (Figs. 2-4) will be formed in a great amount if there is an excess of $\mathrm{OA}$ and reaction time is large. If there are several reactive groups, the formation of all products is possible but with different ratio between them [11].

Taking all mentioned into account, the products composition was evaluated according to the selectivity and yield of HEODA and AEODA (Tables 1-3).

The effect of reagents ratio on the process characteristics is represented in Table 1. The reaction is carried out in the presence of benzene as an entrainer to improve the water removal from the reaction mixture. As it was mentioned above, in all experiments the amount of moles of hydroxy and amine groups in ethanolamines exceeds the amount of carboxy groups in OA. In particular, the ratio OA: MEA:DEA:TEA was 1:(0.02-0.03):(0.25-0.54):(0.24-0.51).

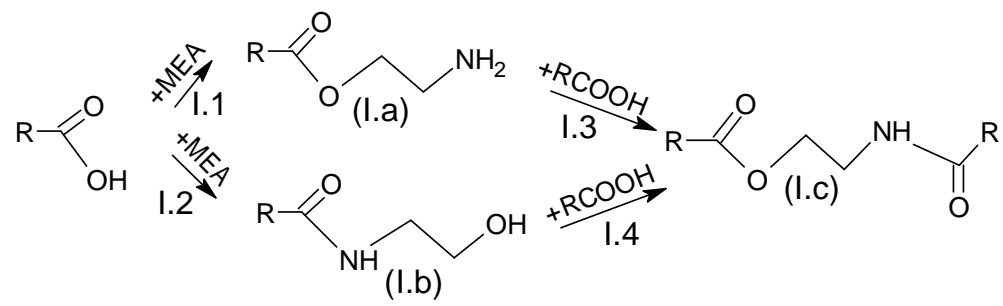

Fig. 2. Scheme of $\mathrm{OA}\left(\mathrm{R}=\mathrm{C}_{17} \mathrm{H}_{33}\right)$ and monoethanolamine conversions: I.a - 2-aminoethyl (9Z)-octadec-9-enoate; I.b - (9Z)-N-(2-hydroxyethyl)octadec-9-enamide; I.c - 2-[(9Z)-octadec-9-enoylamino]ethyl (9Z)-octadec-9-enoate

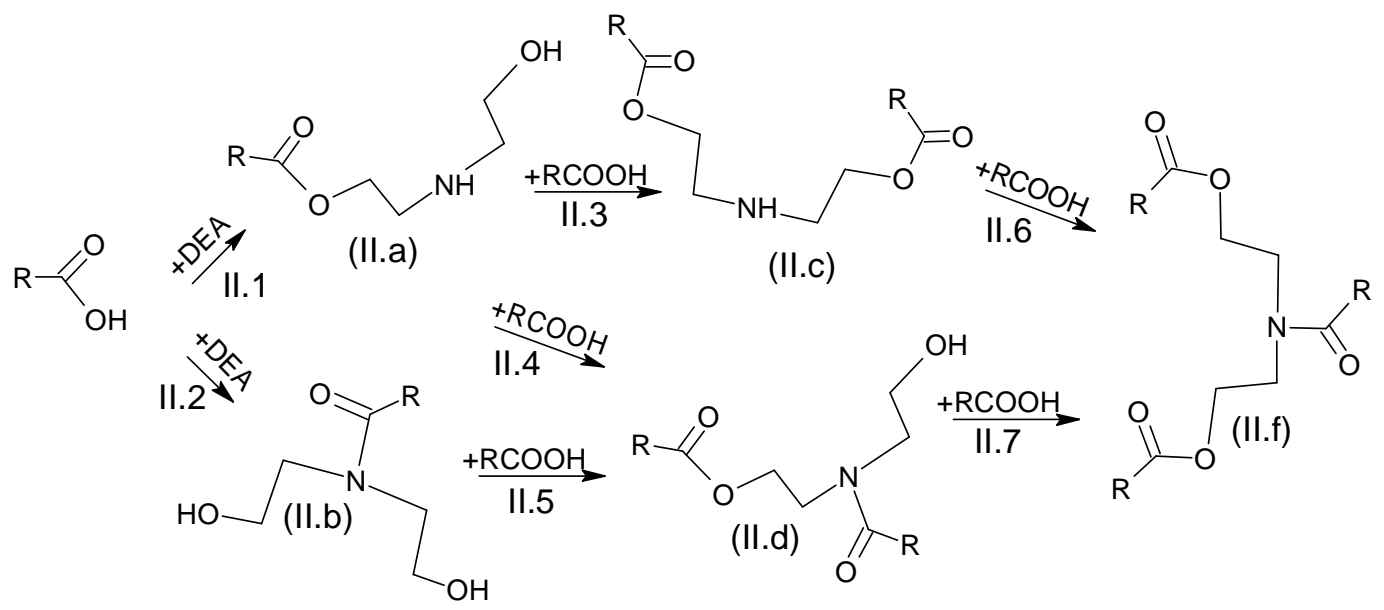

Fig. 3. Scheme of $\mathrm{OA}\left(\mathrm{R}=\mathrm{C}_{17} \mathrm{H}_{33}\right)$ and dioethanolamine conversions: II.a - 2-[(2-hydroxyethyl)amino]ethyl (9Z)-octadec-9-enoate; II.b - (9Z)-N,N-bis(2-hydroxyethyl)octadec-9-enamide; II.c - iminobis(ethane-2,1-diyl) (9Z,9'Z)bis-octadec-9-enoate;

II.d - 2-\{(2-hydroxyethyl) [(9Z)-octadec-9-enoyl]amino\} ethyl (9Z)-octadec-9-enoate;

II.f - [(9Z)-octadec-9-enoylimino]bis(ethane-2,1-diyl) (9Z,9'Z)bis-octadec-9-enoate<smiles>[R]C(=O)OCCN(CCO)CCOC(=O)OCCN(CCOC([R])=O)CCOC([R])=O</smiles>

Fig. 4. Scheme of $\mathrm{OA}\left(\mathrm{R}=\mathrm{C}_{17} \mathrm{H}_{33}\right)$ and triethanolamine conversions: III.a - 2-[bis(2-hydroxyethyl)amino]ethyl (9Z)-octadec-9enoate; III.b - [(2-hydroxyethyl)imino $]$ bis(ethane-2,1-diyl) (9Z,9'Z)bis-octadec-9-enoate;

III.c - (\{[(9Z)-octadec-9-enoyloxy]methyl $\}$ imino)bis(ethane-2,1-diyl) (9Z,9'Z)bis-octadec-9-enoate 
Effect of OA: इEA ratio on the process characteristics $\omega(\mathrm{KU}-2-8) 2.8 \mathrm{wt} \%\left(\mathbf{4 . 2} \cdot 10^{-2} \mathrm{~mol} / \mathrm{dm}^{3} \mathrm{H}^{+}\right), \omega\left(\mathrm{C}_{6} \mathrm{H}_{6}\right) \mathbf{2 8 . 5} \%$, time $125 \mathrm{~min}$, temperature $383 \mathrm{~K}$

\begin{tabular}{|c|c|c|c|c|c|c|c|c|c|}
\hline \multirow{2}{*}{ OA: $\Sigma E A$ (molar ratio) } & $A V_{0}$ & $A V_{\text {fin }}$ & $A m V_{0}$ & $A m V_{\text {fin }}$ & \multirow{2}{*}{ OA conversion, $\%$} & \multicolumn{2}{|c|}{ Selectivity, \% } & \multicolumn{2}{|c|}{ Yield, \% } \\
\hline & $\mathrm{mg}$ & $\mathrm{H} / \mathrm{g}$ & & $\mathrm{Cl} / \mathrm{g}$ & & HEODA & AEODA & HEODA & AEODA \\
\hline $1: 1.1$ & 90.5 & 54.0 & 67.7 & 54.0 & 61.0 & 83.3 & 16.7 & 51 & 10 \\
\hline $1: 0.55$ & 122 & 102 & 33.6 & 29.0 & 39.7 & 39.5 & 60.5 & 16 & 24 \\
\hline $1: 0.51$ & 120 & 107 & 29.9 & 25.2 & 37.9 & 38.9 & 61.1 & 15 & 23 \\
\hline
\end{tabular}

Table 2

Effect of catalyst nature on the process characteristics

$\mathrm{C}\left(\mathrm{H}^{+}\right)$4.2 $\cdot 10^{-2} \mathrm{~mol} / \mathrm{dm}^{3}$, time $125 \mathrm{~min}$, temperature $383 \mathrm{~K}$, OK: $\mathrm{EEA}$ (molar ratio) - 1:1.1

\begin{tabular}{|c|c|c|c|c|c|c|c|c|c|c|}
\hline \multirow{2}{*}{ Catalyst } & \multirow{2}{*}{ Content, wt \% } & $A V_{0}$ & $A V_{\text {fin }}$ & $A m V_{0}$ & $A m V_{\text {fin }}$ & \multirow{2}{*}{ OA conversion, $\%$} & \multicolumn{2}{|c|}{ Selectivity, \% } & \multicolumn{2}{|c|}{ Yield, \% } \\
\hline & & $\mathrm{mg} \mathrm{F}$ & $\mathrm{OH} / \mathrm{g}$ & & $\mathrm{Cl} / \mathrm{g}$ & & HEODA & AEODA & HEODA & AEODA \\
\hline KU-2-8 & 2.9 & 90.5 & 54.0 & 29.9 & 25.2 & 61.0 & 83.3 & 16.7 & 51 & 10 \\
\hline$p$ TSA & 0.8 & 93.2 & 64.5 & 67.4 & 51.0 & 48.2 & 93.9 & 6.1 & 45 & 3 \\
\hline
\end{tabular}

The increase in excess of ethanolamines decreases OA conversion (Table 1). The differences between the initial and final acid and amine values vary indicating the formation of $N$-acylation products and ethanolamines esterification products, as well. The contribution of the mentioned reaction also varies. The decrease in ethanolamines amount from 1.1 to $0.55 \mathrm{~mol} / \mathrm{mol} \mathrm{OA}$ reduces the selectivity relative to HEODA from 83.3 to $39.5 \%$, and increases the selectivity relative to AEODA from 16.7 to $60.5 \%$. The yields change from 51 to $16 \%$ and from 10 to $24 \%$, respectively. Further decrease in ethanolamines amount to $0.51 \mathrm{~mol} / \mathrm{mol} \mathrm{OA}$ does not affect the operational properties.

If we compare two catalysts of the process under the same concentration of $\mathrm{H}^{+}$ions relative to $1 \mathrm{dm}^{3}$ of the mixture, we see that process indices, especially OA conversion, are better when using heterogeneous cationite KU-2-8 compared with homogeneous $p$ TSA (Table 2).

Lower activity of $p$ TSA may be explained by the fact that a part of acid, which is uniformly distributed in all volume, is bounded with ethanolamines (namely with TEA) as a salt:

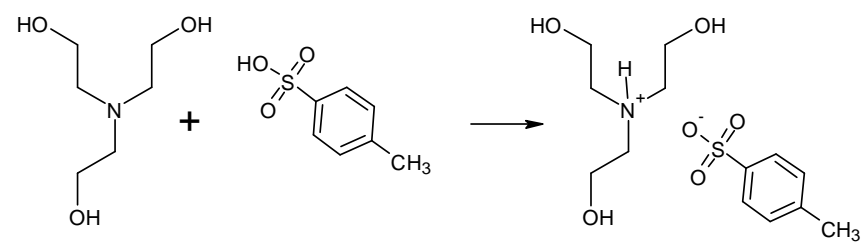

So, the catalyst partially loses its activity. The same phenomenon is observed when a cationite is used. But the cationite $\mathrm{SO}_{3}^{-}$groups localized on the polymeric matrix reduce the frequency of their contact with ethanolamines and the catalytic activity of KU-2-8 remains sufficiently high. We also suppose the less stability of the complexes formed by $\mathrm{SO}_{3}{ }^{-}$groups compared with those formed by $p$ TSA.
So, ion-exchange resin in $\mathrm{H}$-form is a more effective catalyst of the reaction of $\mathrm{OA}$ with ethanolamines. Generally, in the presence of both catalysts the reactions of $\mathrm{N}$-acylation are dominant that is confirmed by high selectivity and yield of HEODA (Table 2).

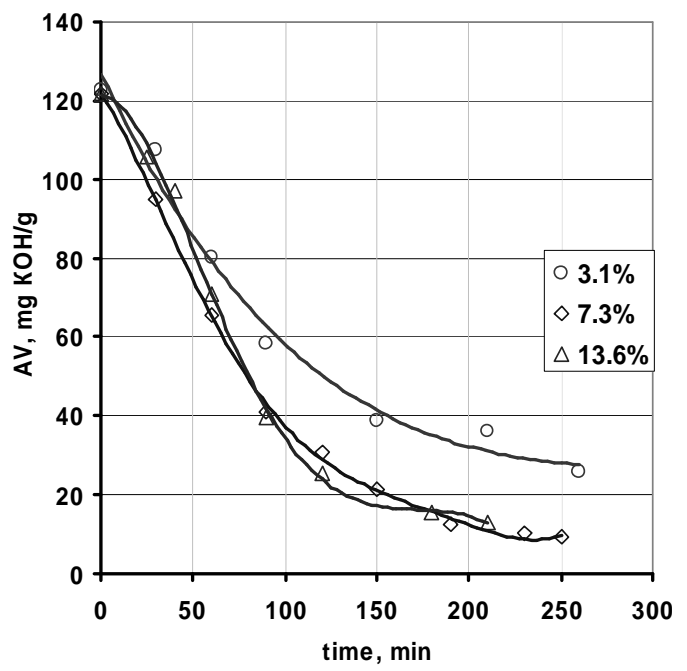

Fig. 5. Acid value $v s$. time at KU-2-8 different concentrations

The experimental results show low efficiency of benzene to remove water from the mixture. Therefore, the effect of KU-2-8 amount on the reaction characteristics was studied without benzene. The reaction temperature of $403 \mathrm{~K}$ was sufficient to remove the formed water. KU-2-8 concentration was varied from 3.1 to $13.6 \mathrm{wt} \%$. The ratio OA:MEA:DEA:TEA was $1:(0.05-0.07):(0.82-0.84):(0.78$ $0.80)$. The process intensity was evaluated according to the change of acid value (Fig. 5). Notably, the increasing resin concentration above $7.3 \mathrm{wt} \%$ does not actually change the acid value. 
Table 3

Effect of KU-2-8 concentration on the process characteristics time $250 \mathrm{~min}$, temperature $403 \mathrm{~K}$

\begin{tabular}{|c|c|c|c|c|c|c|c|c|c|c|c|}
\hline \multirow{2}{*}{$\begin{array}{c}\text { KU-2-8 } \\
\text { content } \\
\text { wt \% }\end{array}$} & \multirow{2}{*}{$\begin{array}{c}\mathrm{C}\left(\mathrm{H}^{+}\right) \cdot 10 \\
\mathrm{~mol} / \mathrm{dm}^{3}\end{array}$} & \multirow{2}{*}{$\begin{array}{c}\text { OA: } \begin{array}{c}\text { EAA } \\
\text { (molar } \\
\text { ratio) }\end{array} \\
\end{array}$} & $A V_{0}$ & $A V_{\text {fin }}$ & $A m V_{0}$ & $A m V_{\text {fin }}$ & \multirow{2}{*}{$\begin{array}{c}\text { OA conversion, } \\
\%\end{array}$} & \multicolumn{2}{|c|}{ Selectivity, \% } & \multicolumn{2}{|c|}{ Yield, \% } \\
\hline & & & & $\begin{array}{l}\mathrm{ig} \\
\mathrm{H} / \mathrm{g}\end{array}$ & $\mathrm{mg}$ & $\mathrm{HCl} / \mathrm{g}$ & & HEODA & AEODA & HEODA & AEODA \\
\hline 3.1 & 0.47 & $1: 1.65$ & 122 & 25.8 & 108 & 60.4 & 81.6 & 79.4 & 20.6 & 65 & 17 \\
\hline 7.3 & 1.2 & $1: 1.70$ & 122 & 10.2 & 110 & 55.4 & 93.6 & 81.6 & 18.4 & 76 & 17 \\
\hline 13.6 & 2.3 & $1: 1.71$ & 122 & 12.9 & 110 & 65.0 & 92.7 & 79.2 & 20.8 & 73 & 19 \\
\hline
\end{tabular}

Using the larger molar excess of ethanolamines $(\mathrm{OA}: \Sigma \mathrm{EA}=1:(1.65-1.71))$, the conversion of 81.6$93.6 \%$ is achieved (Table 3 ).

It should be noted that selectivities of HEODA and AEODA formation are independent of catalyst concentration and equal to 80 and $20 \%$, respectively. The higher yield of $N$-acylation products $(73-76 \%)$ at the resin concentrations of 7.3 and $13.6 \%$ is provided by a higher value of OA conversion.

\section{Conclusions}

During oleic acid reaction with ethanolamines only one conversion direction is dominant depending on reagents ratio and catalyst concentration. Under high excess mono-and diethanolamines react via $\mathrm{N}$-acylation I.2 (Fig. 2) and II.2 (Fig. 3), respectively. Taking into account the selectivity of AEODA formation of 17$20 \%$, the intensity of the reactions I.1 (Fig. 2), II.1 (Fig. 3) and III.1-3 (Fig. 4) is considerably lower. The increase in $\mathrm{OA}$ excess changes the ratio between the reactions intensity toward esterification reaction and provides higher $(\sim 61 \%)$ selectivity of AEODA formation. The increase in the catalyst (ion-exchange resin in $\mathrm{H}$-form) concentration from 3.1 to $13.6 \mathrm{wt} \%$ slightly influences the selectivity. The advantages of cation-exchange resin as the catalyst are the high rate of reagents conversion and simplicity of catalyst separation from the mixture by filtration or decantation.

\section{References}

[1] Pletnev M. (Ed): Poverhnostno-Aktivnye Veschestva i

Kompozitsii. Spravochnik, OOO «Firma Klavel», Moskva 2002.

[2] Pop G., Bodachivskyi Yu., Donets O.: Naftohazova Haluz Ukrainy, 2014, 5, 32.

[3] Akram M., Zaman W., Salman Z. et al.: J. Sci. Res., 2010, 41, 31. [4] Mithun G. Mondal, Amit Prabhakar Pratap: J. Oleo Sci., 2016, 65, 663. https://doi.org/10.5650/jos.ess 15276

[5] Protsyshyn V., Holik M.: Katalyz i Neftekhymyia, 2007, 15, 108. [6] Liu K., Nau A., Shaw J.-F.: J. Agric. Food Chem., 2001, 49, 5761. https://doi.org/10.1021/jf0107858

[7] Chebaksarov A., Khudoleeva E., Besogonov M.: Pat. RU 436767, Publ. Dec. 20, 2011.

[8] Melnyk S., Reutskyy V.: Chem. Chem. Technol., 2014, 8, 93. [9] Mitchell D., Smit D.: Akvametriya. Khimiya, Moskva 1980. [10] Ogorodnikov S. K.: Azeotropnyie Smesi. Khimiya, Leningrad 1971. [11] Abdul Aziz H., Kheireddine Aroua M., Yusoff R. et al.: J. Surfact Deterg., 2016, 19, 11. https://doi.org/10.1007/s11743-015-1736-0

Received: April 26, 2017 / Revised: June 12, 2017 / Accepted: September 05, 2017

\section{ВЗАЕМОДІЯ ОЛЕЇНОВОЇ КИСЛОТИ З ЕТАНОЛАМІНАМИ}

Анотація. Досліджено закономірності взаємодії олеїнової кислоти з сумішшю етаноламінів за нестаціонарних умов у присутності каталізатора - катіонообмінної смоли КУ-2-8 у Н-формі. Визначено вплив співвідношення реагентів $i$ кількості каталізатора на конверсію кислоти та селективність утворення $i$ вихід продуктів. Показано, щзо реакиї $\mathrm{N}$-ацилування моно- $i$ діетаноламінів олеӥновою кислотою відбуваються з вищою інтенсивністю, порівняно з естерифікацією гідроксильних груп етаноламінів.

Ключові слова: олеӥнова кислота, етаноламіни, каталізатор, катіообмінна смола, селективність. 